University of Nebraska - Lincoln

DigitalCommons@University of Nebraska - Lincoln

Faculty Publications from the Harold W. Manter Laboratory of Parasitology

6-30-1945

\title{
The Plains Garter Snake, Thamnophis radix, in Ohio
}

Roger Conant

Zoological Society of Philadelphia

Edward S. Thomas

Ohio State Museum

Robert L. Rausch

University of Washington, rausch@uw.edu

Follow this and additional works at: https://digitalcommons.unl.edu/parasitologyfacpubs

Part of the Parasitology Commons

Conant, Roger; Thomas, Edward S.; and Rausch, Robert L., "The Plains Garter Snake, Thamnophis radix, in Ohio" (1945). Faculty Publications from the Harold W. Manter Laboratory of Parasitology. 378.

https://digitalcommons.unl.edu/parasitologyfacpubs/378

This Article is brought to you for free and open access by the Parasitology, Harold W. Manter Laboratory of at DigitalCommons@University of Nebraska - Lincoln. It has been accepted for inclusion in Faculty Publications from the Harold W. Manter Laboratory of Parasitology by an authorized administrator of DigitalCommons@University of Nebraska - Lincoln. 


\section{5, No. 2 \\ The Plains Garter Snake, Thamnophis radix, in Ohio \\ By Roger Conant, Edward S. Thomas, and Robert L. Rausch}

$\mathrm{T}$

HE announcement that Thamnophis radix, the plains garter snake, occurs in Ohio and is not rare in at least one county, will surprise most herpetologists and students of animal distribution. Since the publication of Ruthven's monograph on the genus (1908), almost all authors have followed his definition of the range of this species, giving eastern Illinois as its easternmost limit. Ruthven (p. 80), however, believed that radix very probably would be found in western Indiana, a supposition since substantiated by Schmidt and Necker (1935: 72), who report the species from the dune region of Lake and Porter counties.

There may be other stations for radix in Indiana, but concrete evidence is lacking. We recently canvassed all members of the American Society of Ichthyologists and Herpetologists who live in that state, but none of them had encountered radix there. Hay (1881: 738) recorded a specimen which he believed to have been taken at Irvington (the italics are ours), and Cope (1888: 400) based his Eutaenia radix melanotaenia (a synonym of radix) upon a snake that, reputedly, came from Brookville. We have been unable to locate the specimens on which either of these records were based. The Brookville locality, lying in the Illinoian drift of the extreme southeastern part of Indiana, is open to question, particularly since other species (Heterodon simus and Hyla squirella), whose ranges probably never included southeastern Indiana, have also been reported from the same town. The snake catalogued in the United States National Museum (No. 25951) as radix from Honey Creek, Vigo County, is actually Thamnophis ordinoides elegans, hence obviously there has been an error either of bookkeeping or of locality.

Thus, while radix is known from the Indiana dunes and may occur elsewhere in that state, no one previously has reported it from Ohio-no one except the late Raymond L. Ditmars. In his Reptile Book (1907: 223), and again in 1936 (p. 141), he gives the range as "western Ohio to the eastern slopes of the Rocky Mountains," and one of the three different ranges he gave for radix in 1939 (p. 223) is the same. While this statement has been generally ignored, it is possible that Ditmars may have received an Ohio radix early in his career. Specimens constantly were being sent to him for identification from all over the country.

There is now adequate proof that radix does occur in Ohio. We are able to present data from fourteen specimens, nine of which have been preserved. These are listed in the order in which they were collected.

1. 2 miles SW of Upper Sandusky, Wyandot County, July 18, 1931 (TMS 767). Found dead on the road by Conant.

2. Southwestern limits of Marion, Marion County, March, 1937. An extremely large specimen, estimated to be nearly $1000 \mathrm{~mm}$. in length. Collected by Rausch.

3. West of Marion, Marion County, spring, 1937-Rausch.

4. Section 33, Grand Prairie Township, Marion County, June, 1937-Rausch.

5. Western outskirts of Marion, Marion County, April, 1938-Rausch.

6. Section 26, Big Island Township, Marion County, September 2, 1940 (OSM 535). Collected by Thomas.

7. Clark's Bridge (over the Scioto River), Montgomery Township, Marion County, May 18, 1941-Rausch. 
8. Section 6, Greencamp Township, Marion County, June 28, 1941 (OSM 536)Rausch.

9. Section 7, Marion Township, Marion County, April 12, 1942 (OSM 537)-Rausch. 10. Section 6, Greencamp Township, Marion County, May 31, 1942 (OSM 538)Rausch.

11. Section 5, Marion Township, Marion County, June 27, 1942 (OSM 539)-Rausch.

12. Greencamp Township, Marion County, August 15, 1942 (ANSP 24735)-Rausch.

13. Section 9, Pitt Township, Wyandot County, August 24, 1942 (OSM 667)Darius Washburn and Thomas.

14. Section 7, Pitt Township, Wyandot County, April 25, 1943 (OSM 670)-Washburn and Thomas.

Letters and numbers in parentheses indicate preserved specimens and their respective museums and catalogue numbers. Toledo Museum of Science No. 767 , the only specimen available for study prior to the publication of the Reptiles of Ohio (Conant, 1938), was therein described in some detail (p. 103 ) as an aberrant Thamnophis s. sirtalis. The junior author first recognized the presence of radix in Ohio and it is his persistent and successful efforts that have brought together a series of specimens.

The scutellation of the preserved snakes is as follows:

\begin{tabular}{|c|c|c|c|c|c|c|c|c|c|c|}
\hline No. & Sex & Scale Rows & $\begin{array}{l}\text { Vent- } \\
\text { rals }\end{array}$ & $\begin{array}{l}\text { Sub- } \\
\text { caud- } \\
\text { als }\end{array}$ & $\begin{array}{l}\text { Labi- } \\
\text { als }\end{array}$ & $\begin{array}{l}\text { Ocu- } \\
\text { lars }\end{array}$ & $\begin{array}{l}\text { Tem- } \\
\text { por- } \\
\text { als }\end{array}$ & $\begin{array}{c}\text { Total } \\
\text { Length } \\
\text { in } \mathrm{mm} .\end{array}$ & $\begin{array}{c}\text { Tail } \\
\text { Length } \\
\text { in } \mathrm{mm} .\end{array}$ & $\begin{array}{l}\text { Tail / } \\
\text { Length/Total } \\
\text { /Length }\end{array}$ \\
\hline $\begin{array}{l}\text { ANSP } 24735 \\
\text { OSM } 538 \\
\text { OSM } 667 \\
\text { OSM } 535 \\
\text { OSM } 536 \\
\text { OSM } 537 \\
\text { OSM } 539 \\
\text { OSM } 670 \\
\text { TMS } 767\end{array}$ & $\begin{array}{l}9^{7} \\
0^{7} \\
9^{7} \\
9 \\
9 \\
0 \\
q \\
q \\
0 \\
9\end{array}$ & $\begin{array}{c}19-21-19-17 \\
19-21-19-17 \\
19-21-19-17 \\
19-21-19-17 \\
19-21-19-17 \\
21-19-17 \\
21-19-17 \\
19-21-19-17 \\
19-21-19-17\end{array}$ & $\begin{array}{l}156 \\
158 \\
154 \\
155 \\
153 \\
151 \\
152 \\
149 \\
151\end{array}$ & $\begin{array}{l}75 \\
76 \\
75 \\
44 \dagger \\
65 \\
28 \dagger \\
66 \\
18 \dagger \\
64\end{array}$ & $\begin{array}{l}7-10 \\
7-10 \\
7-10 \\
7-10 \\
8-10 \\
8-10 \\
8-10 \\
8-10 \\
7-10\end{array}$ & $\begin{array}{l}1-3 \\
1-3 \\
1-3 \\
1-3^{+} \\
1-3,2 \\
1-3 \\
1-3 \\
1-3 \\
1-3\end{array}$ & $\begin{array}{l}1-2 \\
1-2 \\
1-3,2 \\
1-2^{*} \\
1-2 \\
1-2,3 \\
1-2 \\
1-2 \\
1-2\end{array}$ & $\begin{array}{l}512 \\
329 \\
463 \\
757 \dagger \\
431 \\
603 \dagger \\
400 \\
524 \dagger \\
645\end{array}$ & $\begin{array}{c}129 \\
78 \\
113 \\
124 \dagger \\
93 \\
70 \dagger \\
88 \\
50 \dagger \\
137\end{array}$ & $\begin{array}{l}25.2 \% \\
23.7 \% \\
24.4 \% \\
21.6 \% \\
22.0 \% \\
.21 .2 \%\end{array}$ \\
\hline
\end{tabular}

* Head partially crushed; counts could be made only on left side.

$\dagger$ Tail incomplete.

In all particulars these scale counts fall well within the limits of variation given for radix by Ruthven (op. cit.).

All are quite similar in coloration and pattern. A composite description (from life) follows: Middorsal stripe bright orange yellow, occupying the median row of scales and adjoining fractions of the adjacent rows. Lateral stripe bright yellow; situated on scale rows 3 and 4. Dorsal ground color dark chocolate brown. A double row of round black spots on each side of body between the stripes, these approximately 1 to $1 \frac{1 / 2}{2}$ scales in length and about 2 to $2 \frac{1}{2}$ scales in height; the spots often run together and thus obscure the ground color. A row of similar dark spots between the lateral stripe and the ventrals. Belly light greenish grey, each ventral with a conspicuous black spot at each end; sutures between the ventrals often irregularly bordered with black. There is a tendency in some specimens for spots on adjacent ventrals to run together. Similar, but indistinct, markings on the under side of the tail. Top of head and occipital region black or very dark brown, except for a pair of bright yellow parietal spots. Lower labials, chin, and throat uniform pale yellow; sutures between lower labials edged with black in some specimens. Upper labials yellow, their posterior edges broadly bordered with black, especially toward the rear of the head. There are yellow or yellowish areas on the nasals, preoculars, and lower postoculars. 
All nine preserved Ohio specimens have been compared with radix from Illinois and other parts of the range; in general appearance and details of pattern they are in agreement.

Persons using the key in the Reptiles of Ohio will find that Thamnophis radix will check out to section 9 (p. 20). It differs from all other Ohio garter snakes, however, in having a maximum of 21 scale rows (the others have 19); both radix and Thamnophis s. sauritus have the light lateral stripes on the 3 rd and 4th scale rows, but radix has a short tail- $26 \%$ or less of the total length as compared with $28 \%$ or more in sauritus.

It should also be noted that radix has a relatively large and wide head which is considerably different in shape from the narrow head of sauritus and the noticeably small head of butleri.

Of the several specimens we have collected alive some were in the open, sometimes on the prowl; others were hidden beneath various objects as indicated in the section on ecology. Almost all flattened their bodies considerably when they were alarmed or handled, and most of them struck and attempted to bite repeatedly. Those kept captive ate live earthworms, frogs, minnows, and chopped fish.

\section{ECOLOGY ${ }^{1}$}

It is of considerable interest to note that this population of a western species, a great number of miles to the east of any previously known station, should occur in what was once the most extensive single wet prairie area in Ohio. It also is noteworthy that this snake has been able to survive drastic alteration of its former habitat. The original prairie, now some of the most productive farm land in the state, has been almost completely destroyed by cultivation and grazing, and the former prairie vegetation is at present limited to remnants along the roadsides and railroad rights of way and to a few restricted swales which have proved difficult to drain.

The specimens from the immediate vicinity of Marion were taken along railroads, particularly the New York Central System. The rights of way of these are paralleled by broad shallow ditches which, having never been plowed or grazed, support a luxuriant growth of prairie vegetation, probably not differing greatly from that which prevailed originally. Among the characteristic prairie plants occurring there may be mentioned the prairie dock (Silphium terebinthinaceum) ${ }^{2}$ sawtooth sunflower (Helianthus grosseserratus), white wild-indigo (Baptisia leucantha), prairie cordgrass (Spartina pectinata), big bluestem grass (Andropogon furcatus), prairie lily (Lilium michiganense), and many others.

The Big Island Township specimen came from a cultivated field a few hundred feet from the New York Central tracks.

The specimen from Marion Township, Section 7, was found in a shallow prairie swale (dry throughout most of the year) which appeared to have been undisturbed by man in recent years. Among the characteristic plants growing there are the cordgrass, wild-indigo, common reed-grass (Phragmites communis), Virginia mountain-mint (Pycnanthemum virginianum), wild bergamot (Monarda fistulosa), scattered saplings of Crataegus, and such common

1 The discussion of systematics in this paper has been contributed principally by Conant and Rausch; that on ecology principally by Thomas and Rausch.

2 generally available. 
weeds as teasel (Dipsacus sylvestris), common cinquefoil (Potentilla canadensis), Kentucky bluegrass (Poa pratensis), American germander (Teucrium canadense), smooth oxeye (Heliopsis helianthoides), Virginia wild-rye (Elymus virginicus), and the foxglove beard-tongue (Penstemon digitalis).

The locality in Marion Township, Section 5, is an ancient channel of the Little Scioto River, now far removed from the bed of the present stream. It contains water throughout most of the year but becomes dry during the summer months. It appears to have been grazed severely over a long period of time, as is evidenced by the presence of extensive colonies of water smartweed (Polygonum hydropiper). There is, however, a dense growth of marsh vegetation, including a few species that are characteristic of prairie swales. Among the conspicuous plants may be mentioned swamp rose (Rosa palustris), gray dogwood (Cornus racemosa), wing-angled loosestrife (Lythrum alatum), dark-green bulrush (Scirpus atrovirens), fogfruit (Phyla lanceolata), marsh yellow-cress (Rorippa palustris), ditch stonecrop (Penthorum sedoides), and marsh pea (Lathyrus palustris).

One of the specimens from Greencamp Township was taken from beneath a $\log$ in a pasture a few rods from an extensive swale which is an old oxbow of the Scioto River; the second one was found at the border of some sedges. The swale is filled with water except in the driest part of the year. It contains a sizeable colony of buttonbush (Cephalanthus occidentalis), and is bordered by a number of black willows (Salix nigra). In spite of heavy pasturing, there is a good growth of marsh vegetation in and around it. There are dense stands of sedges-Carex spp. and of dark-green bulrush and mild smartweed (Polygonum hydropiperoides). Other characteristic plants are lake watercress (Armoracia aquatica), spatterdock (Nuphar advena), marsh purslane (Ludwigia palustris), ditch stonecrop, swamp persicaria (Polygonum coccineum), and fogfruit. No characteristic prairie or prairie swale vegetation remains, if it were ever present.

The snake from Pitt Township, Section 9, was discovered beneath a shock of oats while the crop was being harvested. The field borders the Sandusky River and is close to a rather extensive prairie swale which shows no evidence of having been plowed or grazed. Part of the swale had been burned some months previously and was covered at the time it was visited with a dense growth of fireweed (Erechtites hieracifolia) and Pennsylvania persicaria (Polygonum pennsylvanicum). There are scattered, scrubby specimens of shingle oak (Quercus imbricaria) and of Crataegus spp. around its border and even invading the swale. In places there are dense stands of tall sedges, cordgrass, and big bluestem, and several colonies of the tall, robust river bulrush (Scirpus fuviatilis). Such characteristic prairie plants as glaucous spiderwort (Tradescantia canaliculata), sawtooth sunflower, and Virginia mountain-mint are also present.

During the threshing operations, in addition to the foregoing specimen, four common garter snakes (Thamnophis sirtalis sirtalis) and one massasauga (Sistrurus catenatus catenatus) were captured.

The specimen from Pitt Township, Section 7, was found near the grassy margin of a small artificial pond in the midst of a cultivated field. It is situated in an excellent example of black-land prairie, but cultivation has destroyed every vestige of the original vegetation. 


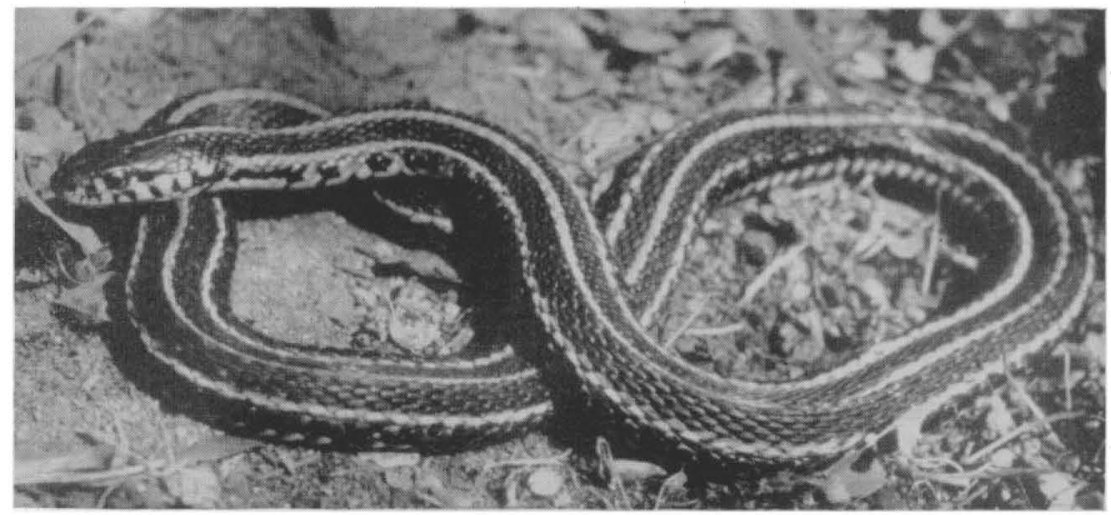

Fig. 1. Adult female specimen of Thamnophis radix collected April 12, 1942, in Section 7, Marion Township, Marion County, Ohio. Color characters are helpful as field recognition marks. The bright orange dorsal stripe and the bright yellow lateral stripes contrast strongly with the dark areas between them. In radix there are extensive black maculations on the labials, types of markings which usually are not well developed (if present at all) on the labials of Thamnophis sirtalis, the only other snake with which radix is very apt to be confused. The head of Thamnophis butleri is, proportionately, very small; Thamnophis sauritus has a narrow head and a long tail. (See text for details.)

Photographs by Edward S. Thomas. 


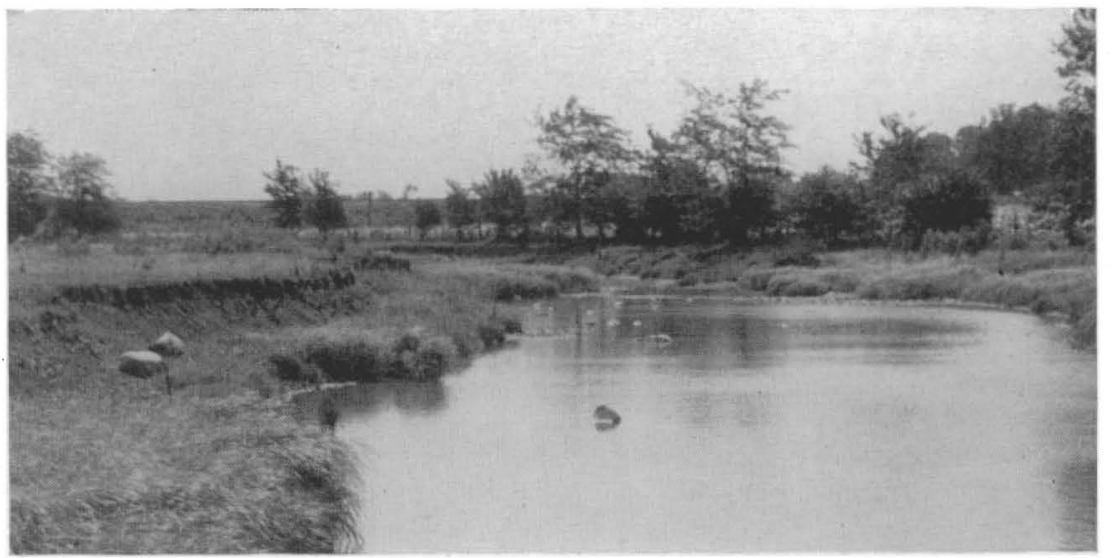

Fig. 2. The Little Scioto River in Section 5, Marion Township, Marion County, Ohio

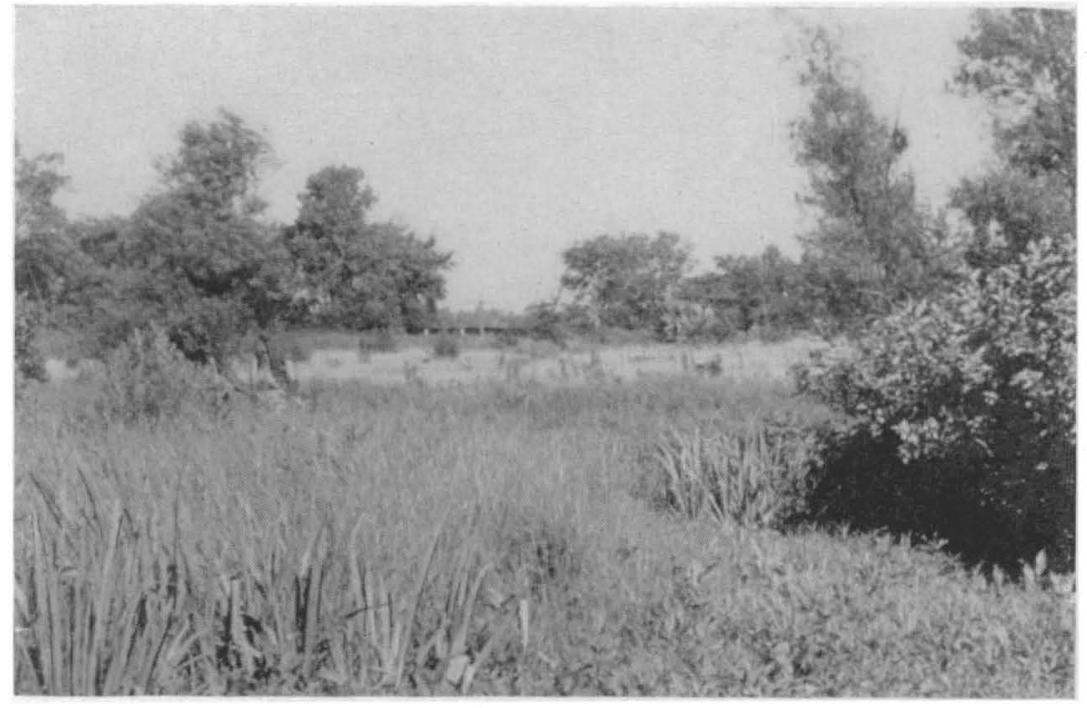

Fig. 3. A swale occupying an old oxbow of the Scioto River, Greencamp Township, Marion County, Ohio. 
All of the foregoing localities are in the midst of a typical, flat, wet prairie country with deep, black soils and sluggish mud-bottomed streams. Few of the specimens of radix, however, were captured in typical prairie land. It will be noted, rather, that all were in, or close to, prairie swales or streams. This was also true of the Montgomery Township specimen, which was found on the bank of the Scioto River. No evidence of prairie habitat was noted in the vicinity, but the river at this place has all the aspects of a typical prairie stream; it is deep and sluggish, with few riffles and with mud banks and bottom.

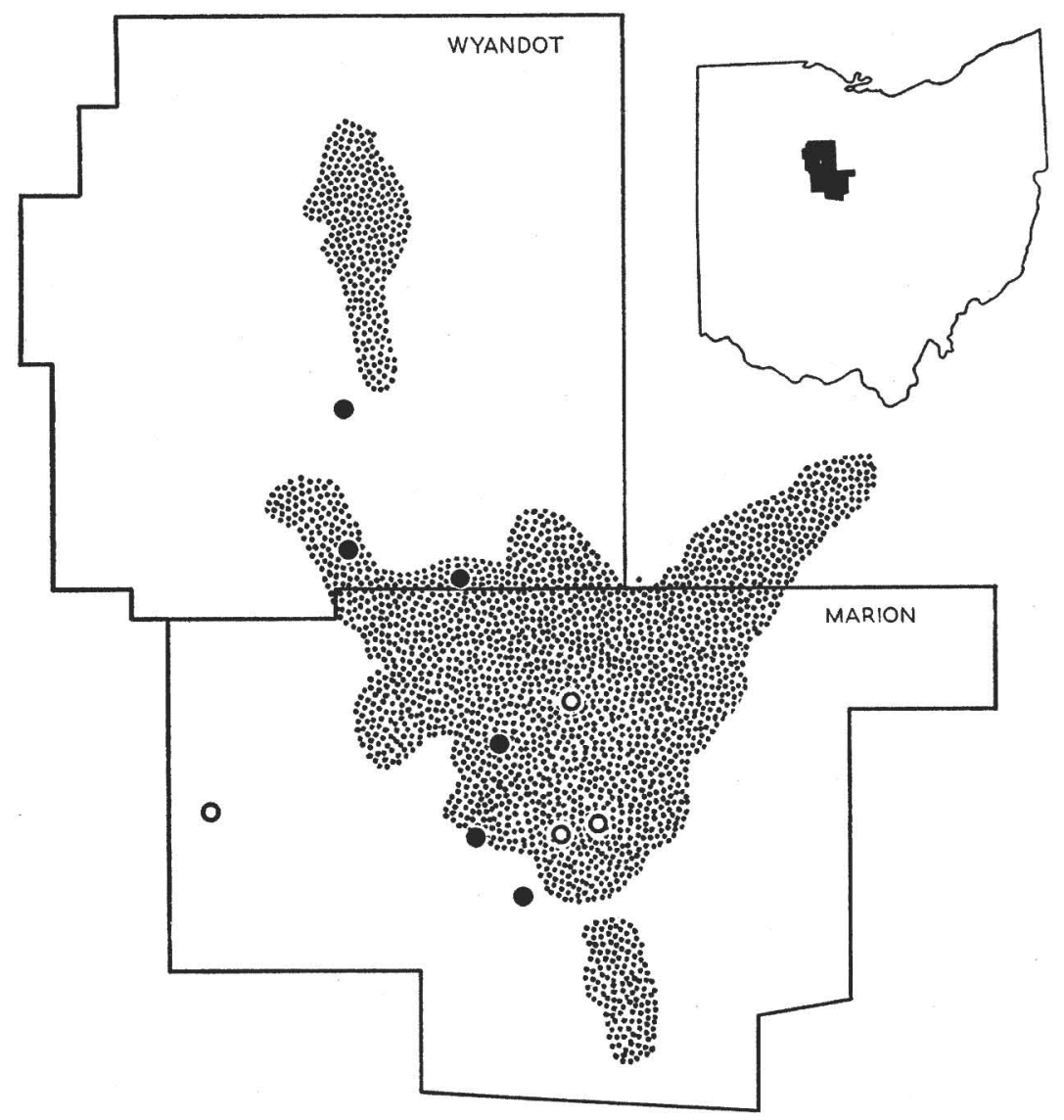

Map 1. Stations for Thamnophis radix in Ohio. Solid circles represent preserved specimens; hollow circles represent additional specimens which were not preserved. The stippled areas show the approximate extent of relict prairies in Marion and Wyandot counties (adapted from Transeau, 1935). The portion of Ohio in which the two counties are situated is indicated on the smaller map (upper right). Maps prepared by Edmond Malnate.

The presence of this western snake in the prairies of Ohio, so far east of any other known colony, would seem to constitute one of the most remarkable 
examples of prairie relict yet recorded. There is always the possibility, of course, that it may have been introduced by human means in historic times, but this seems unlikely. Its very wide distribution throughout the prairie area of western Marion and southern Wyandot counties would indicate that the species has been established in the region for a long time.

Schmidt (1938) has given an admirable review of a number of prairie relict amphibians and reptiles, postulating that these species extended their range from the western prairies following the retreat of the ice in postPleistocene times. He follows many European writers in the opinion that the invasion of our present prairie fauna and flora followed closely after the retreat of the ice, steppe (prairie) succeeding tundra.

There is, indeed, some evidence of a xeric period coincident with or immediately following the last retreat of the Pleistocene ice sheet, as is indicated by Sears' (1942b) review of the European literature. Many European, as well as American, writers, however, find evidence of a much more recent and more pronounced xerothermic period. The analysis of pollens at various profiles of boreal relict bogs indicates the concurrence of five climatic periods in postglacial time: (1) A moist, cool period, with a maximum of fir and spruce; (2) A dry, probably warmer period (the "Boreal" of Sernander, 1911) with a maximum of pine often mixed with oak (that this period was not extensive or pronounced in North America, however, is indicated by the fact that evidence of it is wanting in many American profiles); (3) A more humid; also warm period (the "Atlantic") with a maximum of beech and, in places, of hemlock; (4) A warm, dry period, the Xerothermic Period or "Subboreal," with a maximum of oaks and hickories and a minimum of beech; and (5) The present (probably cooler and with more available moisture than in No. 4). So far as the Prairie Peninsula is concerned, Transeau (1935) has shown that a prairie-like climate still obtains throughout the region, in contrast with the areas to the north, south, and east of the Peninsula.

While there is evidence, in Europe at least, of a considerable extension of steppe species in the Boreal Period, following close after the glacial retreat, it would seem entirely unnecessary to go back so far to account for the present-day prairie fauna, especially in view of the abundant evidence of a pronounced Xerothermic Period in fairly recent geologic time. In fact, it is evident that the warm, humid Atlantic Period, which preceded the Xerothermic, would have been distinctly unfavorable for the survival of any prairie elements which might have come east earlier. Sears (1942a), has shown that during the warm, humid maximum, beech extended its range as far west as Iowa, far beyond its present distribution, while hemlock spread extensively over areas where it is not now present. Both these species of trees are pronounced mesophytes. Similarly, Wilson and Webster (1942) offer fossil evidence of a wider range in Wisconsin of such mesic species as butternut and hickory than now prevails. If the climate during this period was sufficiently humid to have resulted in the wide dispersal of such mesophytic plants, the inference follows that any prairie elements remaining from an early postPleistocene invasion must have been adversely affected, if not completely extirpated, and that we must consequently look to the comparatively recent Xerothermic Period to account for the eastward extension of our present prairie flora and fauna into the prairie Peninsula. 
It seems likely that Thamnophis radix invaded the eastern portions of the Prairie Peninsula during the Xerothermic Period along with other characteristic prairie plants and animals. There it exists today, in isolated prairie relict communities. In view of the apparent rarity of the species, it must be more exacting in its requirements than other more widely distributed and locally abundant prairie species of plants and animals. At the same time, in this region in Ohio, where it occurs in good numbers, it has proved tolerant to changed conditions brought about by agricultural practices.

The distribution of Thamnophis butleri presents an entirely different pattern from that of Thamnophis radix and other prairie relict plants and animals which are believed to have extended their ranges eastward during the Xerothermic Period. The stations for radix appear as disjunct colonies extending like a tongue from the western prairies eastward into the Prairie Peninsula, the colonies tending to become more and more isolated as they approach the eastern tip of the Peninsula.

Thamnophis butleri, on the other hand, is endemic to the eastern part of the Prairie Peninsula and, except for an isolated Wisconsin population, is not known west of the Illinois-Indiana line. It, too, may be considered as a relict of a former climate, since it exists in isolated colonies throughout most of its range. It seems altogether likely, however, that butleri, unlike radix, existed prior to the Wisconsin glaciation somewhere near its present range, as postulated by Schmidt (op. cit.). Persisting throughout Wisconsin times beyond the periphery of the ice sheet, it may have spread into the glaciated portions of the Prairie Peninsula soon after the retreat of the ice.

It is entirely possible that radix will be found in additional prairie or prairie-like areas in other parts of Ohio. It may also be found to occur in Michigan, as is suggested by a specimen (ANSP 6226) labelled "Michigan" and collected by Dr. Miles. It evidently was thought to be sirtalis when caught and it was so catalogued until recently. Judging from the frequency with which radix and sirtalis have been confused, one of the most promising places to search for radix might be in preserved collections of sirtalis!

\section{Literature Cited}

CONANT, ROger

1938 The reptiles of Ohio. Amer. Midl. Nat., 20: 1-200.

COPE, E. D.

1888 On the Eutaeniae of southeastern Indiana. Proc. U.S. Nat. Mus., 11: 399-401. Deam, C. C.

1940 Flora of Indiana. Dept. of Conserv., Indianapolis: 1-1236.

DitmaRs, R. L.

1907 The reptile book. Doubleday, Page, New York: i-xxxii, 1-472.

1936 The reptiles of North America. Doubleday, Doran, New York: i-xvi, 1-476.

1939 A field book of North American snakes. Doubleday, Doran, New York: i-xii, 1-307.

HAY, O. P.

1881 Eutaenia radix in Indiana. Amer. Nat., 15: 738.

RuthVEN, A. G.

1908 Variations and genetic relationships of the garter snakes. Bull. U. S. Nat. Mus., ScHMIDT, K. P. 61: I-XII, 1-201.

1938 Herpetological evidence for the postglacial eastward extension of the steppe in North America. Ecology, 19: 396-407. 
Schmidt, K. P., and W. L. Necker

1935 Amphibians and reptiles of the Chicago region. Bull. Chicago Acad. Sci., 5: 55-77.

SEARS, P. B.

1942a Postglacial migration of five forest genera. Amer. Journ. Botany, 29: 684-691. 1942b Xerothermic theory. Bot. Review, 8: 708-736.

SERNANDER, $R$.

1911 Die Schwedischen Torfmoore als Zeugen postglacialer Klimaschwankungen (in) Die Veränderungen des Klimas seit dem Maximum der letzten Eiszeit. Geol. Congr. Int.: 195-246.

Transeau, E. N.

1935 The prairie peninsula. Ecology, 16: 423-437.

WIISON, L. R. and R. M. WeBSTER

1942 Fossil evidence of wider post-Pleistocene range for butternut and hickory in Wisconsin, Rhodora, 44: 409-414.

Zoological Society of Philadelphia, Pennsylvania, Ohio State Museum, Columbus, Ohio, and Michigan State College, East lansing, MichigaN. 